Tohoku J. exp. Med., 1983, 140, 35-43

\title{
Ghemical Analyses and Antitumor Activity of Hydrosoluble Substances from Mycobacterium bovis, Strain BGG
}

\author{
Hirosi Sato, Hideo Arai, Hiromi Nagai, Masayuki \\ Ito, Ken Satoh, Nobuko Kumano, Masakichi MotomiYa \\ and Kiyoshi Konno \\ Department of Internal Medicine, the Research Institute for \\ Tuberculosis and Cancer, Tohoku University, Sendai 980
}

Sato, H., Arai, H., Nagai, H., Ito, M., Satoh, K., Kumano, N., Motomiya, M. and Konno, K. Chemical Analyses and Antitumor Activity of Hydrosoluble Substances from Mycobacterium bovis, Strain BCG. Tohoku J. exp. Med., 1983, 140 (1), 35-43 — Hydrosoluble substances from BCG were prepared by cold water extraction and by hot phenol-water extraction. Chemical analyses revealed that both of them were derived from cytoplasm. The cold water extract (CWE) was effective in the treatment of $\mathrm{C} 3 \mathrm{H} / \mathrm{He}$ mice which had received an intraperitoneal inoculation of a syngeneic ascites hepatoma, MH134. The growth of a graft in footpad of mastocytoma P815 in $\mathrm{CDF}_{1}$ mice was retarded by intraperitoneal injections of CWE. A peptidoglycan from cell wall prepared by digestion with lysozyme exerted no antitumor activity in the same experimental condition as for the evaluation of antitumor effect of CWE. These results indicate that the antitumor activity of CWE was not due to the presence of a cell wall component. - hydrosoluble substance; BCG; antitumor activity; mastocytoma P815

There are a number of publications dealing with the effects of mycobacteria on immune response and on antitumor activity. Several fractions of mycobacteria have been investigated in order to identify the chemical constituents which are responsible for these activities and as a result cell wall has been found to have these biological activities.

A hot water extract from delipidated BCG, which has been found to be derived from cytoplasm, is adjuvant-active and exhibits weak but significant antitumor activity (Sato et al. 1976, 1978, 1979).

In this study, a cold water extract from delipidated BCG and a phenolwater extract were prepared to compare their antitumor effects with those of a water soluble substance from cell wall isolated by an enzymatic treatment of BCG.

This report deals with the chemical analyses and antitumor activity of the above hydrosoluble substances. 


\section{Materials and Methods}

\section{Bacilli}

Mycobacterium bovis, strain BCG (Japanese strain, Tokyo No. 172, supplied by the National Institute of Health, Tokyo) subcultured for 4 weeks on a modified Sauton medium (Sato et al. 1969) were used throughout this series of experiments.

\section{Preparation of hydrosoluble substances}

The hot water extract (HWE) was prepared from delipidated Mycobacterium bovis, strain BCG, as described previously (Sato et al. 1976). The cold water extract (CWE) was obtained in the course of the preparation of HWE. A suspension in distilled water of defatted BCG was stirred at $4^{\circ} \mathrm{C}$ for an hour and filtered through a Millipore Filter $(0.45 \mathrm{~nm}$, Millipore Filter Corporation, Massachusetts, USA). The precipitate formed by an additon of 3 volumes of acetone was dialysed against running water and then lyophilized.

The phenol-water extract (PWE) was prepared by the method of Cantrell and Wheat (1979) which had been used to obtain phenol-water extract from Corynebacterium parvum. Briefly, $10 \mathrm{~g}$ of dried BCG were suspended in $70 \mathrm{ml}$ of a $1: 1$ mixture of distilled water and phenol. The bacillary suspension was stirred for $30 \mathrm{~min}$ at $65^{\circ} \mathrm{C}$ and then cooled at $4^{\circ} \mathrm{C}$ overnight. The aqueous phase after centrifugation at $2,000 \times \mathrm{g}$ for $30 \mathrm{~min}$ at $4^{\circ} \mathrm{C}$ was concentrated. Ten volumes of ethanol were added to this concentrate. The resulting precipitate was dialyzed against distilled water and lyophilized.

The neo-WSA from BCG was extracted according to the method of Adam et al. (1973). BCG (10 g, dry weight) was delipidated in a Soxhlet apparatus for $24 \mathrm{hr}$ with acetone, ethanol, chloroform and chloroform: methanol $(87: 13)$ in the order described. The defatted cells were washed with 100 times their weight of distilled water containing $0.1 \mathrm{M}$ ammonium acetate, $\mathrm{pH}$ 6.2. The washed cells, suspended in $500 \mathrm{ml}$ of $0.1 \mathrm{M}$ ammonium acetate containing $0.01 \%$ egg white lysozyme (Sigma Chemical Co., St. Louis, USA) were incubated for $18 \mathrm{hr}$ at $37^{\circ} \mathrm{C}$. The residue after filtration was reincubated with lysozyme under the same condition and was filtered again. The two filtrates were united and lyophilized to remove ammonium acetate. The white powder thus obtained was designated crude neoWSA. This crude neo-WSA was fractionated on a column of a Sephadex G-75. Fraction B (Fig. 1) was designated neo-WSA-BCG.

\section{Analytical methods}

Neutral sugars were identified by paper chromatography in the solvent systems of ethyl acetate-acetic acid-formic acid-water $(90: 15: 5: 20)$ and n-butanol-pyridine-water (6:4: $3)$, respectively. Neutral sugar was quantitated by Roe's method (1955) and by phenolsulfuric acid reagent. Pentose was quantitated according to the direction of Dische (1962). Aminosugar was measured by the method of Elson-Morgan as modified by Blix (1948). Ninhydrin-positive substance was estimated as described by Yemm and Cocking (1955). Quantification of nucleic acid was made by the method of Schmidt and Thannhauser (1945) and Schneider (1946).

\section{Antitumor activity}

Animals. Mice for the experiments were purchased from Funabashi Animal Breeder, Shizuoka. The mice were 6 to 8 weeks old at the start of the experiments.

Tumor cells. Sarcoma 180 (S180) and Ehrlich carcinoma (EC) have been maintained in ddY mice by 2 -weekly intraperitoneal passage. MH 134, originally induced with carbon tetrachloride in $\mathrm{C} 3 \mathrm{H}$ mice and converted into ascites form (Sato et al. 1956), has been maintained in $\mathrm{C} 3 \mathrm{H} / \mathrm{He}$ mice by intraperitoneal inoculations. Mastocytoma P815, originally isolated by Dunn and Potter (1957) in DBA/2 mice, has been maintained in ascites by serial intraperitoneal transplantations in histocompatible $\mathrm{CDF}_{1}(\mathrm{BALB} / \mathrm{c} \mathrm{DBA} / 2)$ mice.

Tumor cells were harvested from the abdominal cavity and washed with Hanks' balanced saline solution. Viability, checked by the trypan blue exclusion test, was over $95 \%$. 
Hydrosoluble substances to be tested were dissolved in saline immediately before injection and $0.25 \mathrm{mg}$ each of which in $0.2 \mathrm{ml}$ of saline was injected intraperitoneally for 14 consecutive days from day 1 after inoculation of tumor cells.

Male ddY mice were inoculated intraperitoneally with $5 \times 10^{5}$ cells of S180 or $3 \times 10^{5}$ cells of EC. PWE, CWE and HWE were injected to mice of different groups. The number of survivors and survival days were recorded.

Male $\mathrm{C} 3 \mathrm{H} / \mathrm{He}$ mice received an intraperitoneal inoculation of $\mathrm{MH1} 34$ cells and the survival days were compared. In three experiments to compare the antitumor activity of PWE, CWE and HWE, $5 \times 10^{3}, 8 \times 10^{3}, 1 \times 10^{5}$ cells respectively were inoculated. For the evaluation of the effect of fractions of crude neo-WSA-BCG, $5 \times 10^{3}$ cells were inoculated.

Male $\mathrm{CDF}_{1}$ mice which had received a subcutaneous transplantation of $2 \times 10^{4}$ cells of mastocytoma P815 in the left hind footpad were injected intraperitoneally with PWE, CWE or HWE. The thickness of footpad was compared between experimental and control groups.

Student's $t$-test was used in all statistical evaluations.

\section{Results}

\section{Chemical analyses}

Table 1 shows the results of chemical analyses of PWE, CWE and HWE. Less than $2 \%$ of ninhydrin-positive substance and only a trace of nucleic acids were found in PWE. The amounts of ninhydrin-positive substance and nucleic acids in CWE were less than those in HWE. Paper chromatography revealed that neutral sugars in these three substances consisted mainly of glucose and mannose.

The elution profile of the crude neo-WSA-BCG from a column of Sephadex G-75 is illustrated in Fig. 1. The results of chemical analyses of fractions thus obtained are summarized in Table 2. Fraction D is rich in ninhydrin-positive substance presumably due to the presence of lysozyme in this fraction. Paper chromatography of neutral sugars of these fractions indicated the presence of galactose and arabinose in Fraction B, which suggests that this fraction had been derived from cell wall. Thus it is likely that Fraction B is essentially equivalent to neo-WSA described by Adam et al. (1973).

TABLE 1. Quantitative analyses of hydrosoluble substances

\begin{tabular}{ccccc} 
& $\begin{array}{c}\text { Neutral sugar* } \\
(\%)\end{array}$ & $\begin{array}{c}\text { Amino sugar } \dagger \\
(\%)\end{array}$ & $\begin{array}{c}\text { Ninhydrin-positive } \\
\text { substance }(\%)\end{array}$ & $\begin{array}{c}\text { Nucleic acids§ } \\
(\%)\end{array}$ \\
\hline PWE & 68.5 & 0.6 & 1.0 & 0.2 \\
CWE & 72.5 & 0.8 & 5.6 & 6.2 \\
HWE & 52.8 & 0.8 & 12.5 & 10.8 \\
\hline
\end{tabular}

PWE, phenol-water extract; CWE, cold water extract; HEW, hot water extract. The numerals indicate the mean of three experiments.

Determination: * by Roe's method, $\dagger$ by a modified Elson-Morgan's method, $\ddagger$ by Yemm and Cocking method, and $\S$ by the method of Schmidt and Thannhauser, and of Schneider. 


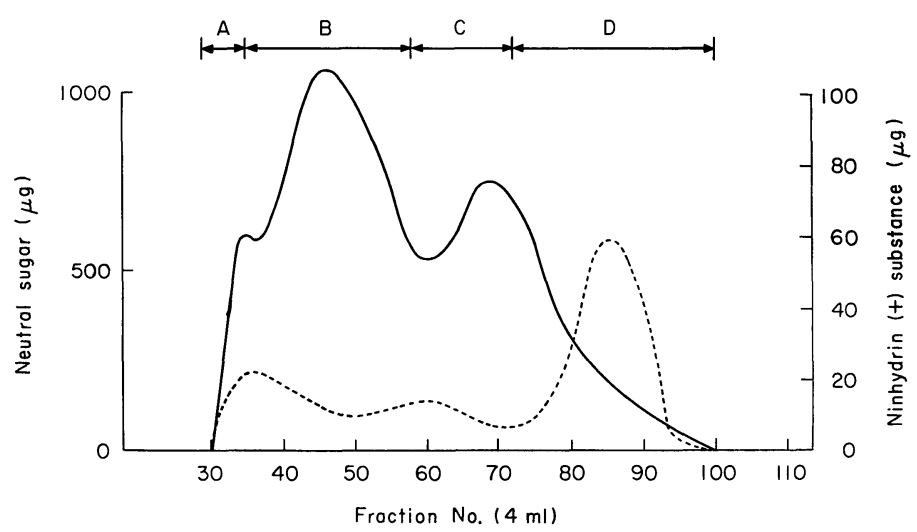

Fig. 1. Elution pattern of $800 \mathrm{mg}$ of crude neo-WSA-BCG from a $2.5 \times 60 \mathrm{~cm}$ column of Sephadex G-75. Elution was effected with $0.1 \mathrm{~N}$ acetic acid. Fractions $(4 \mathrm{ml})$ were analysed for neutral sugar by phenol-sulfuric acid reagent and for ninhydrin-positive substance by the method of Yemm and Cocking (calculated as glycine). neutral sugar; ------, ninhydrin-positive substance.

TABLE 2. Quantitative analyses of fractions of crude neo-WSA-BCG

\begin{tabular}{ccccc} 
Fraction & $\begin{array}{c}\text { Neutral sugar* } \\
(\%)\end{array}$ & $\begin{array}{c}\text { Pentose } \\
(\%)\end{array}$ & $\begin{array}{c}\text { Amino sugar } \\
(\%)\end{array}$ & $\begin{array}{c}\text { Ninhydrin-positive§ } \\
\text { substance }(\%)\end{array}$ \\
\hline Crude neo-WSA & 32.0 & 11.0 & 2.6 & 27.5 \\
A & 50.0 & 4.5 & 2.3 & 18.0 \\
B & 60.5 & 25.0 & 2.6 & 12.4 \\
C & 57.5 & 15.3 & 3.3 & 15.2 \\
D & 21.4 & 4.2 & 1.7 & 58.3
\end{tabular}

The numerals refer to the means of three experiments. Determination: * by Roe's method, † by Dische's method, $\ddagger$ by a modified Elson-Morgan's method, $\S$ by method of Yemm and Cocking.

\section{Antitumor activity}

Antitumor activity on Sarcoma 180 and on Ehrlich carcinoma. As shown in Tables 3 and 4, PWE was not effective under these experimental conditions. The antitumor effect of CWE on Sarcoma 180 was not very strong. However, in the experiment on Ehrlich carcinoma, prolongation of survival time in CWEinjected group was significant. It is apparent that HWE exerted an antitumor activity on Sarcoma 180, whereas there was no difference in survival time between the control group and HWE-treated group in the experiment on Ehrlich carcinoma.

Antitumor activity of neo-WSA-BCG on Sarcoma 180 was compared with that of CWE and HWE (Table 5). Neo-WSA-BCG and HWE were found to be effective. In contrast, CWE was ineffective.

Antitumor activity on mastocytoma P815. As indicated in Table 6, the footpad was thinner in CWE-injected group than in control with statistical significance. 
Antitumor Activity of Hydrosoluble Substances from BCG

TABLE 3. Antitumor activity on Sarcoma 180

\begin{tabular}{ccccc}
\multirow{2}{*}{$\begin{array}{c}\text { Treated } \\
\text { with }\end{array}$} & \multicolumn{4}{c}{ Survivors/Number of mice, at days } \\
\cline { 2 - 5 } & 20 & 30 & 40 & 50 \\
\hline Saline & $5 / 20$ & $0 / 20$ & $0 / 20$ & $0 / 20$ \\
PWE & $6 / 20$ & $1 / 20$ & $1 / 20$ & $0 / 20$ \\
CWE & $8 / 40$ & $4 / 40$ & $4 / 40$ & $2 / 40$ \\
HWE & $10 / 20$ & $8 / 20$ & $8 / 20$ & $8 / 20$ \\
\hline
\end{tabular}

PWE, phenol water extract; CWE, cold water extract; HWE, hot water extract.

Male ddY mice were inoculated intraperitoneally with $5 \times$ $10^{5}$ cells of Sarcoma 180. From day 1 after inoculation of tumor cells, $0.25 \mathrm{mg}$ of each substance in saline was injected intraperitoneally for 14 consecutive days. The number of survivors was recorded.

TABLE 4. Antitumor activity on Ehrlich carcinoma

\begin{tabular}{cccc} 
Group & Number of mice & Treated with & $\begin{array}{c}\text { Survival days } \\
\text { (mean } \pm \text { s.D. })\end{array}$ \\
\hline 1 & 10 & Saline & $22.7 \pm 3.6$ \\
2 & 10 & PWE & $23.3 \pm 2.0$ \\
3 & 20 & CWE & $30.7 \pm 11.9^{*}$ \\
4 & 10 & HWE & $24.2 \pm 5.8$
\end{tabular}

PWE, phenol water extract; CWE, cold water extract; HEW, hot water extract.

Male ddY mice were inoculated intraperitoneally with $5 \times 10^{5}$ cells of Ehrlich carcinoma. From day 1 after inoculation of tumor cells, $0.25 \mathrm{mg}$ of each substance was injected intraperitoneally for 14 consecutive days. Survival time in days of each group was compared.

$* p<0.01$.

TABLE 5. Antitumor activity on Sarcoma 180

\begin{tabular}{|c|c|c|c|c|c|}
\hline \multirow{2}{*}{ Group } & \multirow{2}{*}{ Treated with } & \multicolumn{4}{|c|}{ Survivors/Number of mice, at days } \\
\hline & & 20 & 30 & 40 & 50 \\
\hline 1 & Saline & $4 / 10$ & $0 / 10$ & $0 / 10$ & $0 / 10$ \\
\hline 2 & Neo-WSA-BCG & $5 / 10$ & $4 / 10$ & $4 / 10$ & $3 / 10$ \\
\hline 3 & CWE & $3 / 10$ & $1 / 10$ & $1 / 10$ & $0 / 10$ \\
\hline 4 & HWE & $6 / 10$ & $5 / 10$ & $5 / 10$ & $5 / 10$ \\
\hline
\end{tabular}

CWE, cold water extract; HWE, hot water extract.

Male ddY mice received an intraperitoneal inoculation of $5 \times 10^{5}$ cells of Sarcoma 180. From day 1 after inoculation of tumor cells, $0.25 \mathrm{mg}$ in saline of each substance was injected intraperitoneally for 14 consecutive days. The number of survivors was recorded.

At day 25, no difference in thickness of footpad was observed between PWEinjected and control groups.

Antitumor activity on MH134. The results of three experiments on MH134 are 
TABLE 6. Antitumor activity on mastocytoma P815

\begin{tabular}{cccccc}
\hline \multirow{2}{*}{ Group } & $\begin{array}{c}\text { Number } \\
\text { of mice }\end{array}$ & $\begin{array}{c}\text { Treated } \\
\text { with }\end{array}$ & \multicolumn{3}{c}{$\begin{array}{c}\text { Increase of thickness of footpad }(\mathrm{mm}), \\
\text { at days }\end{array}$} \\
\cline { 4 - 6 } & & \multicolumn{1}{c}{$\mathbf{1 5}$} & 20 & 25 \\
\hline 1 & 10 & Saline & $1.66 \pm 0.38$ & $2.53 \pm 0.31$ & $3.20 \pm 0.62$ \\
2 & 10 & PWE & $1.33 \pm 0.26^{*}$ & $1.93 \pm 0.61^{*}$ & $2.94 \pm 0.37$ \\
3 & 10 & CWE & $1.36 \pm 0.19$ & $1.71 \pm 0.44 \dagger$ & $1.93 \pm 0.37 \dagger$ \\
4 & 10 & HWE & $1.33 \pm 0.42$ & $2.04 \pm 0.20_{\ddagger}^{\ddagger}$ & $2.30 \pm 0.67_{\ddagger}^{\ddagger}$ \\
\hline
\end{tabular}

PWE, phenol water extract; CWE, cold water extract; HWE, hot water extract.

Male $\mathrm{CDF}_{1}$ mice were inoculated with $2 \times 10^{4}$ cells of mastocytoma P815 in the left hind footpad. From day 1 after inoculation of tumor cells, $0.25 \mathrm{mg}$ of each substance in saline was injected intraperitoneally for 14 consecutive days. Thickness of footpad was measured at days 15,20 and 25 .

$* p<0.05, \dagger p<0.01, \ddagger p<0.02$.

TABLE 7. Antitumor activity on MH134

\begin{tabular}{|c|c|c|c|c|c|c|}
\hline \multirow{2}{*}{$\begin{array}{l}\text { Treated } \\
\text { with }\end{array}$} & \multicolumn{2}{|c|}{ Experiment 1} & \multicolumn{2}{|c|}{ Experiment 2} & \multicolumn{2}{|c|}{ Experiment 3} \\
\hline & $\begin{array}{l}\text { Number } \\
\text { of mice }\end{array}$ & $\begin{array}{l}\text { Survival days } \\
\text { (mean } \pm \text { s.D.) }\end{array}$ & $\begin{array}{l}\text { Number } \\
\text { of mcie }\end{array}$ & $\begin{array}{l}\text { Survival days } \\
\text { (mean } \pm \text { s.D.) }\end{array}$ & $\begin{array}{l}\text { Number } \\
\text { of mice }\end{array}$ & $\begin{array}{c}\text { Survival days } \\
\text { (mean } \pm \text { s.D.) }\end{array}$ \\
\hline Saline & 10 & $21.0 \pm 3.9$ & 10 & $17.2 \pm 1.0$ & 10 & $16.2 \pm 0.4$ \\
\hline PWE & 10 & $25.9 \pm 7.1$ & 10 & $20.8 \pm 1.8 \dagger$ & 20 & $18.1 \pm 4.6$ \\
\hline CWE & 20 & $26.4 \pm 4.5 \dagger$ & 20 & $22.8 \pm 5.9 \dagger$ & 20 & $16.4 \pm 4.4$ \\
\hline HWE & 10 & $25.0 \pm 3.5^{*}$ & 10 & $19.7 \pm 2.1 \dagger$ & 10 & $18.4 \pm 5.7$ \\
\hline
\end{tabular}

PWE, phenol water extract; CWE, cold water extract; HWE, hot water extract. $* p<0.05, \dagger p<0.01$.

Male $\mathrm{C} 3 \mathrm{H} / \mathrm{He}$ mice were inoculated intraperitoneally with $5 \times 10^{3}$ cells of MH134 in Experiment 1, with $8 \times 10^{3}$ cells in Experiment 2 and with $1 \times 10^{5}$ cells in Experiment 3 . From day 1 after inoculation of tumor cells, $0.25 \mathrm{mg}$ of each substance in saline was injected intraperitoneally for 14 consecutive days. Survival time in days of each group was compared.

TABLE 8. Antitumor activity on MH134 of the fractions from crude neo-WSA-BCG

\begin{tabular}{|c|c|c|c|}
\hline Group & Number of mice & Treated with & $\begin{array}{c}\text { Survival days } \\
\text { (mean } \pm \text { s.D.) }\end{array}$ \\
\hline 1 & 10 & Saline & $20.4 \pm 4.2$ \\
\hline 2 & 10 & $\begin{array}{c}\text { Crude } \\
\text { Neo-WSA-BCG }\end{array}$ & $27.7 \pm 6.5^{*}$ \\
\hline 3 & 10 & $\begin{array}{c}\text { Fraction B } \\
\text { (Neo-WSA-BCG) }\end{array}$ & $20.7 \pm 2.5$ \\
\hline 4 & 10 & Fraction D & $19.5 \pm 2.9$ \\
\hline \multicolumn{4}{|c|}{$\begin{array}{l}* p<0.02 \text { as compared with group } 1 \text {. } \\
\text { Male } \mathrm{C} 3 \mathrm{H} / \mathrm{He} \text { mice were inoculated intraperitoneally } \\
8 \times 10^{3} \text { cells of } \mathrm{MH} 134 \text {. From } 1 \text { day after inoculation } \\
\text { umor cells, } 0.25 \mathrm{mg} \text { of each fraction was injected intra- } \\
\text { toneally for } 14 \text { consecutive days. Survival time in days } \\
\text { ach group was compared. }\end{array}$} \\
\hline
\end{tabular}


summarized in Table 7. In two experiments in which $5 \times 10^{3}$ and $8 \times 10^{3}$ cells of MH134 respectively had been inoculated, significant prolongation of survival time was observed in CWE-treated and in HWE-treated groups. In PWE-injected group, survival time was prolonged only in one experiment. When $1 \times 10^{5}$ cells had been inoculated, none of the three substances was effective.

The antitumor activity on MH134 of neo-WSA-BCG and Fraction D as well as crude neo-WSA-BCG was evaluated (Table 8). The survival time of the group which had been injected with crude neo-WSA-BCG was prolonged. No prolongation of survival time, however, was observed in mice that had received neo-WSA-BCG or Fraction D.

\section{Discussion}

Mycobacteria and taxonomically related microorganisms such as corynebacteria and nocardia have been used in immunotherapy on experimental neoplasms. Since 1972, several adjuvant-active, hydrosoluble substances have been isolated from these microorganisms. However, only a few publications are available concerning the in vivo antitumor effect of the water-soluble substances. Mathé et al. (1973, 1975) reported that a water soluble substance from BCG described by Hiu (1972) was not effective in an attempt of immunoprophylaxis against murine neoplasms. Cantrell and Wheat (1979) reported that inoculation into mice of a mixture of tumor cells and a hot phenol-water extract from Corynebacterium parvum provided no significant protection. On the other hand, regression of tumor was observed in rat by an intralesional injection of a hydrosoluble product from Nocardia opaca (Barot-Ciorbaru 1981).

The hot water extract (HWE) from delipidated BCG has been found to be adjuvant-active and effective in the treatment of murine ascites tumors (Sato et al. 1976, 1978, 1979). Also evidence for host-mediated antitumor activity of HWE has been presented (Sato et al. 1982).

In this study, a cold water extract (CWE) from delipidated BCG and a phenolwater extract (PWE) were prepared. The fraction of neutral sugars of CWE and PWE was found to consist of glucose and mannose, which indicates that these substances were derived from cytoplasm. The antitumor activity of CWE was observed in mice which had been inoculated with syngeneic tumor cells, whereas no significant antitumor effect was observed in the treatment of ddY mice in which allogeneic tumor cells of Sarcoma 180 had been transplanted. The biological activities of mycobacteria and of related microorganisms have been ascribed mainly to the fraction of cell wall. Thus it was necessary to investigate the antitumor activity of the substance obtained from cell wall fraction. A peptidoglycan was isolated from BCG by an enzymatic treatment which had been used by Adam et al. (1973) for the preparation of a water soluble adjuvant from Mycobacterium smegmatis. In this series of experiments a fraction obtained by column chromatography was found to be derived from cell wall and designated neo-WSA-BCG. When neo-WSA-BCG was injected in the same manner as for 
the evaluation of antitumor effect of CWE and HWE, no prolongation of survival time was observed in $\mathrm{C} 3 \mathrm{H} / \mathrm{He}$ mice which had been inoculated intraperitoneally with MH134 cells. Thus, it seems unlikely that the antitumor effect of CWE as well as of $\mathrm{HWE}$ is due to the participation of cell wall component.

Efficacy of an RNA fraction from Mycobacterium tuberculosis H37Ra and Corynebacterium parvum in the treatment of murine experimental cancer has been reported (Millman et al. 1974, 1976, 1977). CWE and HWE which contain nucleic acids are effective, whereas PWE and neo-WSA-BCG which are devoid of nucleic acids are ineffective. Motomiya et al. (1981) found no significant antitumor effect of a subfraction of HWE which contained only a trace of nucleic acids.

Thus it would be of importance to investigate whether nucleic acids contribute to the antitumor activity of hydrosoluble substances. Experiments are now carried out along this line.

\section{References}

1) Adam, A., Ciorbaru, R., Petit, J.F., Lederer, E., Chedid, L., Lamensans, A., Parant, F., Parant, M., Rosselet, J.F. \& Berge, F.F. (1973) Preparation and biological properties of water-soluble adjuvant fractions from delipidated cells of Mycobacterium smegmatis and Nocardia opaca. Infect. Immun., 7, 855-861.

2) Barot-Ciorbaru, R., Petit, J.F., Chassoux, D. \& Salomon, J.C. (1981) Antitumor activity of intralesionally administered Nocardia opaca preparations in rat and mouse tumors: A comparison with BCG and Corynebacterium parvum. Int. J. Immunopharmacol., 3, 115-122.

3) Blix, G. (1948) The determination of hexosamines according to Elson and Morgan. Acta chem. scand., 2, 467-473.

4) Cantrell, J.L. \& Wheat, R.W. (1979) Antitumor activity and lymphoreticular stimulation properties of fractions isolated from Corynebacterium parvum. Cancer Res., 39, 3554-3563.

5) Dische, Z. (1962) Color reactions of pentose. In: Methods in Carbohydrate Chemistry, edited by R.L. Whistler \& M.L. Wolform, Academic Press, New York-London, p. 484.

6) Dunn, T.B. \& Potter, M. (1957) A transplantable mast-cell neoplasm in the mouse. J. nat. Cancer Inst., 18, 587-595.

7) Hiu, I.J. (1972) Water-soluble and lipid free fraction from BCG with adjuvant and antitumor activity. Nature New Biol., 238, 241-242.

8) Mathé, G., Kamel, M., Dezfulian, M., Halle-Pannenko, O. \& Bourut, C. (1973) An experimental screening for systemic adjuvants of immunity. Applicable in cancer immunotherapy. Cancer Res., 33, 1987-1997.

9) Mathé, G., Halle-Pannenko, O., Florentin, I., Bruley-Rosset, M., Kamel, M., Hiu, I.J. $\&$ Bourut, C. (1975) The second generation of EORTC-ICIG experimental screening for systemic immunity adjuvants. Its significance for cancer immunotherapy. A comparison of BCG and its hydrosoluble extract. Europ. J. Cancer, 11, 801-807.

10) Millman, I., Maguire, H.C., Youmans, G.P. \& Youmans, A.S. (1974) Effect of the H37Ra strain of $M$. tuberculosis and of a mycobacterial RNA fraction on tumor growth. Proc. Soc. exp. Med., 147, 765-768.

11) Millman, I., Scott, A.W., Halbherr, T., Youmans, A.S. \& Youmans, G.P. (1976) Mycobacterial nucleic acid: Comparison with mycobacterial cell wall fractions for regression of murine tumor growth. Infect. Immun., 14, 929-933.

12) Millman, I., Scott, A.W. \& Halbherr, T. (1977) Antitumor activity of Propionibacterium ances (Corynebacterium parvum) and isolated cytoplasmic fractions. Cancer Res., 37, 4150-4155. 
13) Motomiya, M., Sato, H., Arai, H., Nagai, H., Ito, M., Satoh, K., Kumano, N. \& Konno, K. (1981) Chemical and biological properties of subfractions of hot-water extract from delipidated BCG. Tohoku J. exp. Med., 133, 293-300.

14) Roe, J.H. (1955) The determination of sugar in blood and spinal fluid with anthrone reagent. J. biol. Chem., 212, 335-343.

15) Sato, H., Belkin, N. \& Essner, E. (1956) Experiments on an ascites hepatoma. III. The conversion of mouse hepatoma into the ascites form. J. nat. Cancer Inst., 17, 1-21.

16) Sato, H., Motomiya, M., Fukushi, K., Fujimoto, M. \& Oka, S. (1969) Wax D fraction from an unclassified mycobacterium strain. J. Bacteriol., 100, 469-474.

17) Sato, H., Yokosawa, A., Arai, H., Nagai, H., Kurita, K., Kumano, N., Motomiya, M. \& Konno, K. (1976) Chemical and biological properties of hot water extract from delipidated cells of Mycobacterium bovis strain BCG. Tohoku J. exp. Med., 120, 75-81.

18) Sato, H., Yokosawa, A., Arai, H., Nagai, H., Kumano, N., Motomiya, M. \& Konno, K. (1978) Antitumor activity of hot-water extract from delipidated BCG. Tohoku J. exp. Med., 125, 247-252.

19) Sato, H., Motomiya, M., Yokosawa, A., Arai, H., Nagai, H., Kumano, N. \& Konno, K. (1979) A biological study on hot water extract from delipidated Mycobacterium bovis strain BCG. Tohoku J. exp. Med., 129, 285-293.

20) Sato, H., Arai, H., Nagai, H., Ito, M., Satoh, K., Kumano, N., Motomiya, M. \& Konno, K. (1982) Evidence for host-mediated antitumor activity in the treatment of experimental tumor with a hot water extract from BCG. Tohoku J. exp. Med., 136, 67-74.

21) Schmidt, G. \& Thannhauser, S.J. (1945) A method for the determination of desoxyribonucleic acid, ribonucleic acid and phosphoprotein in animal tissues. J. biol. Chem., 161, 83-89.

22) Schneider, W.C. (1946) Phosphorous compounds in animal tissues. III. A comparison of methods for the estimation of nucleic acids. J. biol. Chem., 164, 747-751.

23) Yemm, E.W. \& Cocking, E.C. (1955) The determination of amino acids with ninhydrin. Analyst, 80, 209-213. 